\title{
EFEKTIVITAS PELAKSANAAN PEMBELAJARAN TEMATIK TERPADU KURIKULUM 2013 PADA SEKOLAH DASAR DI KECAMATAN BATU LAYAR KABUPATEN LOMBOK BARAT
}

\author{
Lu'luin Najwa ${ }^{1}$, Ahmad Muslim² \\ FIP IKIP Mataram \\ lu'luinnajwa@ikipmataram.ac.id \\ ahmadmuslim82@ikipmataram.ac.id
}

\begin{abstract}
Abstrak: Kurikulum 2013 merupakan kurikulum yang berbasis pada tema. Salah satu pertimbangan yang digunakan dalam pengembangan kurikulum tematik ini adalah proporsi keragaman dalam banyak mata pelajaran. Hasilnya adalah satu tema dalam Kurikulum 2013 dapat berisikan substansi dari beberapa mata pelajaran. Tidak sedikit problematika yang dapat ditemukan dalam implementasi pembelajaran tematik ini, mulai dari kompetensi guru yang harus menyesuaikan diri dengan tuntutan kurikulum, siswa yang dihadapkan pada kuantitas materi yang tidak sedikit, dan orang tua yang hampir semuanya tidak memiliki pengetahuan dan pemahaman yang cukup mengenai pembelajaran tematik. Penelitian ini dilakukan untuk mengetahui bagaimana implementasi pembelajaran tematik yang terjadi di dalam kelas, dan dipotret dari perspektif guru dan siswa. Penelitian merupakan penelitian evaluasi dengan fokus pada aspek transactions, salah satu komponen evaluasi dalam Countenance Model dari Stake. Data dikumpulkan dengan angket dan wawancara, kemudian dianalisis secara deskriptif, dan dibandingkan dengan kriteria normatif. Hasil penelitian menunjukkan bahwa (1) dari pesepektif guru, sebanyak 88,60\% guru telah dapat mengimplementasikan pembelajaran tematik yang sudah direncanakan sebelumnya, (2) sebanyak 76,47\% guru telah dapat melaksanakan tahapan penilaian hasil belajar dengan baik, dan (3) dari perspektif siswa, sebanyak 54\% telah menunjukkan keaktifan yang diharapkan ketika mengikuti proses pembelajaran tematik, dan sebanyak $46 \%$ masuk dalam kategori cukup. Berdasarkan hasil tersebut, diantara saran yang dapat diberikan adalah bagaimana guru, sebagai individu yang bertanggung jawab dalam proses pembelajaran di kelas, dapat menstimulus siswa untuk dapat lebih aktif dalam proses pembelajaran di kelas. Orientasi Kurikulum 2013 yang lebih pada studentscentered harus lebih dapat diwujudkan dalam kegiatan belajar mengajar di kelas.
\end{abstract}

\section{Kata Kunci: Efektivitas, Pelaksanaan Pembelajaran, Kurikulum 2013}

\begin{abstract}
The 2013 curriculum is a theme-based curriculum. One of the considerations used in its construction is the proportion of diversity in many subjects. The result is that a theme in the Curriculum 2013 contains the substance of several subjects. Among the problems found in the implementation of this thematic learning are starting from the competence of teachers who have to adjust to the demands of the curriculum, students who are faced with a large quantity of material, and the parents who almost all do not have sufficient knowledge and understanding on thematic learning. This research aims at revealing how the implementation of thematic learning that occurs in the classroom, and portrayed from the perspective of the teacher and students. This is an evaluation research with a focus on aspects of transactions of Stake's Countenance Model. The data was collected by questionnaire and interview, then analyzed descriptively, and compared with normative criteria. The results shows that (1) based on the teacher perspectives, $88.60 \%$ of them are able to implement thematic learning, (2) $76.47 \%$ of teachers had been able to carry out the stages of assessment of learning outcomes well, and (3) from the perspective of students, $54 \%$ of the them have shown the activeness expected when following the thematic learning process, and as many as 46\% fall into the sufficient category. The suggestion that can be given is how the teacher, as an individual who is responsible for the learning process in the classroom, can stimulate students to be more active in the learning process in the classroom given that the Curriculum 2013 is student-centered.
\end{abstract}




\section{Keywords: Effectiveness, Transactions, The Curriculum 2013}

\section{LATAR BELAKANG}

Kurikulum 2013 telah berusia sekitar 6 tahun, dan dalam perjalanannya, cukup dinamika yang dialaminya. Kurikulum ini pertama kali ditetapkan pada era Menteri Pendidikan dan Kebudayaan dijabat oleh $\mathrm{M}$ Nuh di masa akhir pemerintahan Presiden SBY. Penerapan Kurikulum 2013 ini antara lain didasarkan pada hasil evaluasi yang dilakukan Kemendikub yang antara lain menyimpulkan bahwa kurikulum yang sebelumnya digunakan belum dapat mempersiapkan generasi untuk tiga dasawarsa ke depan (Nuh, 2016). M Nuh yang juga menjadi penggagas Kurikulum 2013 menyatakan bahwa kurikulum sebelumnya, yaitu KTSP, adalah kurikulum yang tidak sesuai dengan UU 20/2003 tentang Sisdiknas. Menurut Nuh, amanat pendidikan yang terdapat di UU Sisdiknas menekankan pada 3 kompetensi, yaitu pengetahuan, keterampilan, dan sikap. Tiga kompetensi ini, menurut Nuh, tidak termuat dalam KTSP (Nuh, 2014). Dinamika kemudian menjadi menarik ketika Kemendikbud setelah era M Nuh, yaitu Anies Baswedan, pada tahun 2014 memutuskan untuk tidak lagi melanjutkan penerapan Kurikulum 2013 dan sekolah-sekolah diminta untuk kembali menggunakan KTSP (okezone.com). Jika ditingkat pembuat kebijakan terjadi perbedaan pendapat yang cukup tajam, maka dapat dibayangkan bagaimana kondisi di sekolah yang menjadi tempat implementasi kurikulum.

Implementasi Kurikulum 2013, sebagai sebuah kurikulum dengan format yang jauh berbeda dengan kurikulum sebelumnya, juga mengalami kendala yang tidak sedikit. Wahyuni \& Berliani (2019) menyebutkan setidaknya 3 permasalahan yang dihadapi guru dalam implementasi Kurikulum 2013, yaitu 1) pada saat penyusunan rencana pelaksanaan pembelajaran, 2) pada saat penerapan pendekatan scientific learning, dan 3) pada saat penilaian pembelajaran yang menggunakan format lebih kompleks. Rusianto (2017) yang meneliti impelementasi Kurikulum 2013 di mata pelajaran Penjasorkes menemukan bahwa guru memiliki respon yang positif terhadap kurikulum ini, namun dalam tataran implementasinya, guru mengakui jika masih belum berjalan dengan baik.

Secara filosofis, Kurikulum 2013 memuat ide pengembangan manusia Indonesia yang paripurna. Disebutkan bahwa kurikulum ini diharapkan dapat membentuk manusia Indonesia yang produktif, kreatif, inovatif, dan afektif, melalui penguatan sikap, keterampilan, dan pengetahuan yang terintegrasi (Kemendikbud, 2014a). Dengan Kurikulum 2013, siswa akan dibina untuk tidak hanya tahu tentang apa (kognitif), tapi juga tahu tentang bagaimana (psikomotor), dan tahu tentang kenapa (afektif). Tantangan yang lebih nyata kemudian muncul ketika kurikulum ini masuk tahapan implementasi. Pendekatan ilmiah dijadikan sebagai dasar dalam setiap kegiatan pembelajaran. Pendekatan ilmiah yang terdiri dari observing, questioning, associating, experimenting, dan creatingnetworking-communicating-

implementing(Kemendikbud, 2014b),menjadi tidak mudah untuk diimplementasikan di banyak kondisi pembelajaran. Konsep pendekatan ilmiah tersebut tentu ideal, namun guru sebagai penanggung jawab kegiatan pembelajaran di kelas membutuhkan waktu yang beravariasi untuk dapat menerapkan pendekatan ini.

Diskusi mengenai kurikulum memang bukan merupakan materi yang sederhana. Ketika kata "kurikulum" disebutkan, asosiasi yang terbangun adalah itu mengenai sesuatu yang lebih dari sekedar materi pelajaran yang akan diberikan kepada siswa. Pembahasan mengenai kurikulum tidak hanya tentang substansi mata pelajaran, atau mengenai bagaimana suatu materi pelajaran diajarkan, tapi juga pembicaraan panjang mengenai landasan filosofis bagaimana sebuah kurikulum terbentuk. Batasan yang dapat dijadikan acuan dalam membahas kurikulum adalah antara lain definisi yang disebutkan dalam UU 20/2003 tentang Sisdiknas, yaitu kurikulum merupakan seperangkat rencana dan pengaturan mengenai tujuan, isi, dan bahan pelajaran, serta cara yang digunakan sebagai pedoman penyelenggaraan kegiatan pembelajaran untuk mencapai tujuan pendidikan nasional.

Secara historis, perjalanan kurikulum pendidikan Indonesia sudah dimulai sejak 
sebelum Indonesia menjadi sebuah negara merdeka. Secara institusional, kurikulum pendidikan nasional sudah melalui beberapa kali perubahan, yaitu tahun 1947, 1952, 1964, 1968, 1975, 1984, 1994, 2004 (KBK), 2006 (KTSP), dan terakhir tahun 2013 dengan nama Kurikulum 2013. Setiap perubahan kurikulum yang dilakukan didasarkan pada tujuan untuk lebih meningkatkan kualitas pendidikan nasional, dalam pengertian bahwa potensi peserta didik dapat berkembang secara optimal.

Sebagaimana yang telah disebutkan dalam bagian awal tulisan ini, implementasi Kurikulum 2013 sarat akan dinamika. Substansi kurikulum yang cukup berbeda dan menawarkan pembelajaran tematik, menghadirkan kesulitan tersendiri bagi guru sebagai penanggung jawab kegiatan pembelajaran di kelas. Setelah lebih dari 5 tahun diimplementasikan, seperti apakah kondisi riil di sekolah, apakah kendala-kendala yang muncul di awal-awal implementasi kurikulum ini sudah dapat teratasi atau belum? Apakah siswa dapat mengikuti kegiatan belajar dengan baik? Penelitian ini dilakukan untuk mencoba menjawab pertanyaan-pertanyaan tersebut, sehingga dapat diperoleh gambaran yang lebih baik mengenai bagaimana Kurikulum 2013 diimplementasikan, khususnya di jenjang pendidikan sekolah dasar.

\section{METODE PENELITIAN}

Penelitian ini merupakan penelitian evaluasi dengan basis model yang digunakan adalah model Countenance dari Stake dan fokus pada aspek transactions. Sumber data ditetapkan secara purposive, yaitu dengan responden guru dan siswa SD yang terdapat pada wilayah Kecamatan Batu Layar. Guru dan siswa juga ditetapkan secara purposive menjadi sampel, sehingga hasilnya nanti akan relevan dengan sekolah asal responden.

Metode pengumpulan data yang digunakan adalah angket, observasi dan wawancara. Metode utama pengumpulan data adalah angket, sedangkan metode lainnya adalah metode pelengkap. Data hasil penelitian kemudian dianalisis menggunakan metode statistik deskriptif dan analisis $\chi^{2}$. Kriteria efektivitas komponen adalah jika jumlah kategori "baik" yang diperoleh adalah sama dengan atau lebih dari $80 \%$.

\section{HASIL DAN PEMBAHASAN}

Secara konseptual, cakupan transaction sebenarnya cukup luas. Stake menyebutkan bahwa fase transaksi berarti tahapan dimana proses aktual belajar mengajar terjadi. Contohnya antara lain seperti kemampuan guru dalam penyampaian materi, strategi pengajaran yang digunakan, kondisi kelas dan kondisi siswa pada saat pembelajaran, dan lain sebagainya. Dalam penelitian ini, tahapan transaksi dibatasi pada bagaimana pelaksanaan pembelajaran tematik yang dilakukan oleh guru dan keaktifan siswa dalam mengikuti pembelajaran tematik di dalam kelas.

\section{Efektivitas Transactions pada Kelompok Guru}

Jumlah guru yang menjadi responden adalah sebanyak 35 orang guru. Dari kualifikasi pendidikannya, mayoritas guru memiliki kualifikasi S1, dan hanya 2 orang dengan pendidikan diploma.

Tabel 1. Distribusi Guru Berdasarkan Pendidikan

\begin{tabular}{|c|c|c|c|}
\hline No & $\begin{array}{c}\text { Pendidikan } \\
\text { Terakhir }\end{array}$ & Frekuensi & Persentase \\
\hline 1 & D2 & 1 & 2.86 \\
\hline 2 & D2 PGSD & 1 & 2.86 \\
\hline 3 & S1 & 22 & 62.86 \\
\hline 4 & S1 B Ind & 1 & 2.86 \\
\hline 5 & S1 PAI & 2 & 5.71 \\
\hline 6 & S1 PGSD & 7 & 20.00 \\
\hline 7 & S2 & 1 & 2.86 \\
\hline \multicolumn{2}{r|}{ Jumlah } & 35 & 100 \\
\hline
\end{tabular}


Dilihat dari masa kerjanya, proporsi guru dengan masa kerja antara 10 hingga 20 tahun adalah yang terbanyak, yaitu sekitar $54,29 \%$ dari 35 orang guru yang menjadi responden. Jika dilihat dari masa kerjanya, maka dapat diasumsikan bahwa guru-guru yang menjadi responden penelitian telah memiliki pengalaman yang cukup baik dalam melaksanakan tugas pengajaran.

Tabel 2. Distribusi Guru Berdasarkan Masa Kerja

\begin{tabular}{|c|c|c|c|}
\hline No & Masa Kerja & Frekuensi & Persentase \\
\hline 1 & $<10$ tahun & 7 & 20 \\
\hline 2 & $10-20$ tahun & 19 & 54.29 \\
\hline 3 & 20 tahun $<$ & 9 & 25.71 \\
\hline \multicolumn{2}{|c|}{ Jumlah } & 35 & 100 \\
\hline
\end{tabular}

Berdasarkan kelas yang diajarkan, distribusi guru relatif merata pada semua kelas. Sebaran ini dilakukan secara proporsional sehingga akan dapat memberikan gambaran mengenai bagaimana karakteristik guru pada suatu kelas tertentu.

Tabel 3. Distribusi Guru Berdasarkan Kelas yang Diajarkan

\begin{tabular}{|c|c|c|}
\hline $\begin{array}{c}\text { Kelas yang } \\
\text { Diajarkan }\end{array}$ & Frekuensi & Persentase \\
\hline Kelas 1 & 5 & 14.29 \\
\hline Kelas 2 & 7 & 20.00 \\
\hline Kelas 3 & 5 & 14.29 \\
\hline Kelas 4 & 5 & 14.29 \\
\hline Kelas 5 & 7 & 20.00 \\
\hline Kelas 6 & 6 & 17.14 \\
\hline Jumlah & 35 & 100 \\
\hline
\end{tabular}

Hasil analisis deskriptif menunjukkan bahwa rata-rata masa kerja guru yang menjadi responden adalah 16,40 tahun, dengan masa kerja terpendek adalah 3 tahun dan masa kerja terlama adalah 36 tahun. Rata-rata jumlah jam mengajar guru adalah 26,37 jam dengan jumlah jam terendah 24 jam, dan tertinggi 36 jam. Sedangkan untuk skor angket Pemahaman terhada Kurikulum 2013, rerata skor yang diperoleh adalah 3,40 dengan rerata skor terendah 2,67 dan tertinggi 3,92.

Tabel 4. Statistik Karakteristik Guru

\begin{tabular}{|c|c|c|c|}
\hline $\begin{array}{c}\text { Karakteristik } \\
\text { Guru }\end{array}$ & $\begin{array}{c}\text { Nilai } \\
\text { Terendah }\end{array}$ & $\begin{array}{c}\text { Nilai } \\
\text { Tertinggi }\end{array}$ & Rerata \\
\hline $\begin{array}{c}\text { Masa Kerja } \\
\text { (tahun) }\end{array}$ & 3 & 36 & 16.40 \\
\hline
\end{tabular}

\begin{tabular}{|c|c|c|c|}
\hline $\begin{array}{c}\text { Jumlah Jam } \\
\text { Mengajar } \\
\text { (per minggu) }\end{array}$ & 24 & 36 & 26.37 \\
\hline $\begin{array}{c}\text { Rerata Skor } \\
\text { Responden }\end{array}$ & 2.67 & 3.92 & 3.40 \\
\hline
\end{tabular}

Pengukuran berikutnya dilakuakn

terhadap aspek-aspek atau komponen yang dilakukan guru pada saat implementasi pembelajaran tematik terpadu. Terdapat 25 aspek yang diukur. Hasil pengukuran dapat disajikan dalam tabel kategorisasi sebagai berikut.

Tabel 5. Kategorisasi Skor Butir Implementasi Pembelajaran Tematik Terpadu

\begin{tabular}{|c|c|c|c|}
\hline No & Kategori & Frekuensi & Persentase \\
\hline 1 & Baik & 21 & 84 \\
\hline 2 & Cukup & 2 & 8 \\
\hline 3 & Kurang & 2 & 8 \\
\hline \multicolumn{2}{|c|}{ Jumlah } & 25 & 100 \\
\hline
\end{tabular}

Berdasarkan Tabel 5 di atas, implementasi pembelajaran tematik terpadu oleh guru SD di Kecamatan Batulayar dapat dikatakan sudah efektif, karena lebih dari $80 \%$ masuk pada kategori "baik". Namun demikian, proporsi sebesar $8 \%$ untuk kategori cukup dan kurang perlu dikritisi. Dengan persentase $84 \%$, mengindikasikan bahwa masih terdapat ruang bagi guru untuk dapat meningkatkan kinerjanya menjadi lebih baik lagi.

\section{Efektivitas Transactions pada Kelompok Siswa}

Aspek transactions pada kelompok siswa dibatasi pada aspek keaktifan siswa dalam mengikuti kegiatan pembelajaran tematik di kelas. Siswa yang menjadi responden terdistribusi pada semua tingkatan, mulai dari kelas 1 hingga kelas 6. Kesiapan belajar siswa diukur menggunakan angket yang terdiri dari 6 butir pernyataan/pertanyaan. Hasil analisis data dapat disajikan sebagai berikut.

Tabel 6. Distribusi Skor Angket Keaktifan Siswa

\begin{tabular}{|c|c|c|c|}
\hline No & $\begin{array}{c}\text { Rerata } \\
\text { Skor }\end{array}$ & Frekuensi & Persentase \\
\hline 1 & $1.00-2.50$ & 6 & 12 \\
\hline
\end{tabular}




\begin{tabular}{|c|c|c|c|}
\hline 2 & $2.51-3.00$ & 17 & 34 \\
\hline 3 & $3.01-3.50$ & 22 & 44 \\
\hline 4 & $3.51-4.00$ & 5 & 10 \\
\hline \multicolumn{2}{|c|}{ Jumlah } & 50 & 100 \\
\hline
\end{tabular}

Jumlah siswa yang menjadi responden adalah sebanyak 50 orang. Distribusi skor rerata pada Tabel 6menunjukkan pola yang mengikuti sebaran normal, dimana proporsi skor tengah lebih banyak dibandingkan skor rendah atau tinggi. Rentang skor 3,01 hingga 3,50 memiliki frekuensi 22 dengan persentase $44 \%$. Rerata skor total yang diperoleh adalah sebesar 3,10 dengan rerata skor terendah 2,33, rerata skor tertinggi 4 , dan simpangan baku 0,427 .

Hasil kategorisasi skor kesiapan siswa adalah sebagai berikut.

Tabel 7. Distribusi Kategori Skor Angket Kesiapan Siswa

\begin{tabular}{|c|c|c|c|}
\hline No & Kategori & Frekuensi & Persentase \\
\hline 1 & Baik & 27 & 54 \\
\hline 2 & Cukup & 23 & 46 \\
\hline 3 & Kurang & 0 & 0 \\
\hline \multicolumn{2}{|c|}{ Jumlah } & 50 & 100 \\
\hline
\end{tabular}

Kondisi ideal dari keaktifan siswa dalam mengikuti pembelajaran tematik adalah lebih dari sekedar berada pada kategori "cukup". Tentunya tidak mudah untuk membuat seluruh siswa mencapai kondisi kesiapan yang baik. Deskripsi skor di atas dapat dijadikan sebagai salah satu gambaran mengenai bagaimana efektivitas implementasi Kurikulum 2013 secara keseluruhan. Jumlah siswa dengan kategori keaktifan "baik" memang lebih dari 50\%, namun angka $46 \%$ untuk kategori "cukup" adalah angka yang sangat besar, hampir mencapai separuh dari responden siswa. Karena efektivitas atau standar efektif tidaknya suatu aspek didasarkan pada kriteria minimal $80 \%$ berada pada kategori "baik", maka hasil deskripsi kategorisasi skor keaktifan siswa ini menunjukkan bahwa siswa belum cukup efektif dalam mengikuti pembelajaran menggunakan Kurikulum 2013.

Keaktifan siswa dalam mengikuti pembelajaran menggunakan Kurikulum 2013 diukur menggunakan instrumen angket yang terdiri dari 6 butir. Hasil analisis deskriptif terhadap butir angket menunjukkan bahwa total rata-rata skor yang diperoleh adalah 3,93.
Dari 8 butir yang dianalisis, terdapat 3 butir angket yang memperoleh rata-rata skor dibawah 3, yaitu untuk butir 9, 10, dan butir 11. Dengan perolehan skor yang dibawah ratarata 3 ini berarti bahwa guru atau pihak sekolah perlu berusaha lebih baik lagi untuk meningkatkan keaktifan siswa dalam kegiatan pembelajaran tematik.

\section{Pembahasan}

Efektifitas berasal dari kata efektif yang dalam bahasa Inggris yaitu effective berarti berhasil atau sesuatu yang dilakukan berhasil dengan baik. Mahmudi (2005:92) mendefinisikan efektivitas merupakan hubungan antara output dengan tujuan, semakin besar kontribusi (sumbangan) output terhadap pencapaian tujuan, maka semakin efektif organisasi, program atau kegiatan. Muhidin (2009) juga menjelaskan bahwa efektivitas juga berhubungan dengan masalah bagaimana pencapaian tujuan atau hasil yang diperoleh, kegunaan atau manfaat dari hasil yang diperoleh, tingkat daya fungsi unsur atau komponen, serta masalah tingkat kepuasan pengguna atau client. Menurut Gibson et.al (Bungkaes, 2013) efektivitas diartikan sebagai penilaian yang dibuat sehubungan dengan prestasi individu, kelompok, dan organisasi.

Padanan kata efektivitas dalam Bahasa Indonesia adalah keberhasilan, dimana suatu program dikatakan efektif jika ia berhasil mencapai tujuan dari program tersebut (Iqbal, 2018). Efektivitas dan keberhasilan kemudian juga dikaitkan dengan kata kualitas, dimana sekolah yang efektif dan berhasil, akan disebut sebagai sekolah yang berkualitas.

Dari beberapa pengertian efektivitas di atas, benang merah yang dapat ditarik adalah bahwa efektivitas lebih berhubungan dengan sejauh mana sebuah program dapat mencapai tujuan yang telah ditetapkan sebelumnya. Jika dikaitkan dalam konteks penelitian, maka penelitian efektivitas lebih merupakan sebuah penelitian evaluatif yang akan membandingkan kenyataan yang terjadi dengan kriteria atau standar yang ditentukan lebih dulu.

Kriteria mengenai efektif tidaknya suatu program, adalah suatu yang kompleks, karena berbicara program berarti berbicara mengenai suatu rangkaian pekerjaan yang dimulai sejak analisis kebutuhan, hingga penentuan ketercapaian target atau tujuan. Salah satu kriteria yang lazim digunakan untuk 
menentukan efektivitas adalah hasil yang dicapai. Jika program yang dievaluasi merupakan program pendidikan atau sekolah, maka ia akan dikatakan efektif jika hasil belajar siswa memenuhi kriteria yang telah ditentukan terlebih dahulu. Namun tentu saja, penetapan kriteria efektivitas merupakan hal rumit, dan tidak mudah untuk disepakati.

Temuan penelitian terkait efektivitas transactionspada guru adalah bahwa secara kesuluruhan guru yang menjadi responden penelitian telah dapat melaksanakan pembelajaran tematik dengan baik atau efektif. Dari 25 aspek pelaksanaan pembelajaran tematik, sebanyak 25 aspek atau $84 \%$ telah dilaksanakan dengan baik, dan masing-masing 2 aspek dengan kategori cukup dan kurang.

Efektivitas pembelajarna tematik ini nampaknya tidak dapat dilepaskan dari kualifikasi pendidikan yang dimiliki. Sebagian besar guru adalah lulusan S1 yang secara administratif telah memiliki kelayakan sebagai seorang guru. Peran stakeholders yang lain juga tidak boleh dikesampingkan. Usia Kurikulum 2013 yang menginjak tahun ke-6 mengindikasikan bahwa sosialisasi telah banyak dilakukan oleh dinas terkait. Peningkatan pemahaman guru melalui pelatihan tentunya telah berulang kali dilakukan. Di lingkup internal sekolah, penguatan oleh manajemen sekolah juga tidak jarang dilakukan. Dengan penguatan yang berulang melalui berbagai kesempatan, maka tentu menjadi lumrah jika guru semakin lebih baik dalam penerapan pembelajaran tematik Kurikulum 2013.

Temuan penelitian yang sedikit berbeda adalah terkait efektivitas transactions untuk kelompok siswa. Dari 50 orang siswa yang menjadi responden, terdapat 27 siswa, atau sekitar $54 \%$ yang masuk dalam kategori "baik", dan 23 siswa atau sekitar $46 \%$ dengan kategori "cukup". Berdasarkan hasil ini, terlihat jelas bahwa ruang perbaikan untuk meningkatkan keaktifan siswa dalam mengikuti pembelajaran tematik menggunakan Kurikulum 2013 masih terbuka lebar. Siswa sebanyak $46 \%$ dengan kategori keaktifan "cukup" merupakan angka yang sangatbesar. Jika responden ini merupakan representasi yang layak terhadap populasinya, maka akan semakin banyak siswa yang harus lebih ditingkatkan keaktifannya dalam pembelajaran tematik menggunakan Kurikulum 2013.

Temuan penelitian ini tidak jauh berbeda dengan hasil penelitian yang dilakukan oleh Rumahlatu dkk (2016) yang menyimpulkan bahwa terdapat beberapa faktor yang menjadi penghambat dalam implementasi Kurikulum 2013, yaitu tidak adanya buku pegangan bagi guru dan siswa, kesiapan guru dan siswa yang belum optimal secara mental, dan penyebarannya yang belum mencakup seluruh sekolah. Temuan kedua dalam penelitian Rumahlatu tersebut, khususnya terkait dengan kesiapan siswa, adalah sesuai dengan temuan penelitian ini.

Dua temuan penelitian ini dapat dijadikan jawaban terhadap pertanyaan yang mungkin dimunculkan: bagaimana efektivitas implementasi Kurikulum 2013 pada tahapan proses; bagaimana hasil belajar siswa ketika belajar menggunakan Kurikulum 2013. Program adalah suatu rangkaian kegiatan yang saling terkait antara satu aspek dengan aspek yang lain. Ketika terdapat kekurangan pada salah satu aspek, maka tentu akan berpengaruh terhadap aspek yang lain. Ketika guru belum optimal dalam implementasi pembelajaran tematik menggunakan Kurikulum 2013, maka siswa juga akan menjadi pihak yang menerima konsekuensinya. Tidak hanya siswa akan tidak dapat mengikuti pembelajaran dengan baik, tapi juga capaian siswa dalam bentuk hasil belajar tidak dalam hasil yang ideal..

Tahapan implementasi sebuah program adalah tahapan yang memiliki peran signifikan menentukan hasil akhir dari program tersebut. Tahap awal tentunya juga berpengaruh. Namun ketika suatu program sudah dipersiapkan dengan baik, namun di tahap implementasi tidak optimal, maka hasil akhir yang diperoleh yang menjadi target program tersebut akan sulit tercapai.

Kegiatan pembelajaran tidak hanya berbicara mengenai bagaimana kesiapan guru, tapi juga tidak boleh melupakan bagaimana kondisi siswa. Pengkondisian siswa harus dilakukan sedemikian rupa, sehingga mereka dapat lebih siap dalam mengikuti pembelajaran menggunakan Kurikulum 2013 (Najwa \& Muslim, 2019).Jika prasyarat di tahap awal telah terpenuhi, maka guru dituntut untuk optimal dalam mengelola kelas yang diampunya. Kompetensi-kompetensi yang harus melekat pada guru harus dapat diterapkan dalam kegiatan pembelajaran.

Kelas sendiri merupakan lingkungan sosial kecil, namun bersifat kompleks. Kelas berisikan individu-individu yang heterogen, 
dalam banyak hal. Kemampuan guru dalam mengelola kelas menjadi signifikan untuk dapat meningkatkan peran aktif siswa dalam kegiatan pembelajaran. Khususnya dalam implementasi Kurikulum 2013, dimana siswa dituntut untuk lebih aktif, atau berbasis student-centered, maka guru memegang fungsi strategis untuk meningkatkan efektivitas pembelajaran di kelas.

\section{KESIMPULAN}

Kesimpulan yang dapat ditarik dari penelitian ini adalah sebagai berikut.

1. Aspek transactions dari aspek butir yang diukur, dalam hal implementasi pembelajaran tematik Kurikulum 2013, telah menunjukkan hasil yang sesuai dengan harapan. Sebanyak 25 aspek atau sekitar $84 \%$ telah berjalan denagn baik, dan dan masing-masing sebanyak 2 apek yang kategori "cukup" dan "kurang".

2. Aspek transactions dari kelompok siswa menunjukkan bahwa proporsi siswa yang dengan kategori keaktifan "baik" adalah sebanyak 27 siswa atau sekitar 54\%, dan sebanyak 23 siswa atau sekitar 46\% dengan kategori "cukup".

\section{DAFTAR PUSTAKA}

8.

9. UU No 20 Tahun 2003 tentang Sistem Pendidikan Nasional.

10. Mulyasa, E., 2014., Pengembangan dan Implementasi Kurikulum 2013. Bandung: PT. Remaja Rosdakarya.

11. 2015. Guru dalam Implementasi Kurikulum 2013. Bandung: PT. Remaja Rosda Karya.

12. Aisyah Nur Rahmawati Identifikasi Masalah yang Dihadapi Guru dalam Penerapan Kurikulum 2013 Revisi di SD. Indonesian Journal of Primary Education Vol .2, No. 1 (2018) 114-123 http://ejournal.upi.edu/index.php/IJPE/inde x.

13. Iqbal, Muhammad, Efektivitas Penyelenggaraan Pendidikan dan Alternatif Pendekatan Penelitian Efektivitas, Jurnal Visionary Volume 5 Nomor 1 Edisi April 2018 ISSN (25034669).
1. M Nuh, 2014, diambil dari https://nasional.tempo.co/read/450576/mnuh-kurikulum-2013-harus-bertahan-15tahun/full\& view=ok.

2. M Nuh, 2013, diambil dari https://www.liputan6.com/news/read/2146 272/eks-mendikbud-m-nuh-blak-blakanperalihan-ktsp-ke-kurikulum-2013.

3. https://news.okezone.com/read/2014/12/13 /65/1078818/polemik-kurikulum-2013anies-salahkan-m-nuh.

4. Rina Wahyuni \& Teti Berliani, Problematika Implementasi Kurikulum 2013 di Sekolah Dasar, diambil dari http://journal2.um.ac.id/index.php/jmsp/art icle/view/6349.

5. Erlan Dwi Rusianto, Refleksi Respon Guru terhadap Penerapan Kurikulum 2013 dalam Pembelajaran Pendidikan Jasmani Olahraga dan Kesehatan di SMP Negeri 1 Ngaglik, diambil dari https://eprints.uny.ac.id/53264/1/skripsi\%2 Ofull\%20pdf.pdf.

6. Kemendibud, 2014-a, diambil dari https://www.kemdikbud.go.id/kemdikbud/ dokumen/Paparan/Paparan\%20Mendikbud \%20pada\%20Workshop\%20Pers.pdf.

7. Kemendibud, 2014-b, https://www.kemdikbud.go.id/kemdikbud/ dokumen/Paparan/Paparan\%20Wamendik. pdf.

14. Rumahlatu, Dominggus., Huliselan, K. Estevanus., Takaria, Johanis. An Analysis of the Readiness and Implementation of 2013 Curriculum in The West Part of Seram District, Maluku Province, Indonesia. International Journal of Environmental \& Science Education 2016. Vol 11 No 12. Diakses pada tanggal 19 April 2019 pukul 17.38 Wita. 